\title{
Global digital divide: reassessing the evidence behind ICT and its contribution to trade among the ICT haves and have-nots In developing economies
}

\author{
Debbra Toria Anak Nipo \\ Imbarine Bujang \\ Hamizah Hassan
}

Faculty of Business Management

Universiti Teknologi MARA, Malaysia

Keywords

ICT, digital divide, developing economies

\begin{abstract}
With regard to the trade sector, information and communication technology (ICT) is seen as a tool that not only helps to promote productivity, but also improve trade competitiveness. Previous studies have shown significant and positive contributions of ICT to trade, however such evidence may not necessarily be true for countries that have relatively lower level of ICT uptake, particularly those at the undesirable end of digital divide. This paper assesses the impact of ICT on trade measured in terms of merchandise and services, on 42 upper middle income countries (ICT haves) and 21 low income countries (ICT have-nots), separately, from 2007 to 2014. Using panel OLS and Generalized Method of Moments (GMM) estimation methods, findings revealed that ICT has no significant impact on either type of trade in low income countries, whereas more advanced forms of ICT namely, mobile cellular and the Internet emerge significant for upper middle income countries. These results suggest that level of ICT may still be at infancy in low income countries, while the ICT-enabled trade in upper middle income countries is already showing increased merchandise trade and service trade from the use of modern technologies.
\end{abstract}

Corresponding author: Imbarine Bujang

Email addresses for corresponding author: imbar074@sabah.uitm.edu.my

First submission received: $13^{\text {th }}$ June 2017

Revised submission received: $30^{\text {th }}$ August 2017

Accepted: $16^{\text {th }}$ October 2017

\subsection{Introduction}

In today's digital age, life without information and communication technologies (ICT) is something hard to imagine for many. The booming of ICT took the center stage during the 1990s due to its multidimensional impacts and transformation of economic, social, political and cultural aspects of life. With increased efficiency in processes and support for innovation, ICT helps businesses to achieve substantial cost reduction and boost its overall productivity. Not only are ICT-enabled trade activities and transactions cost-effective, ICT also cuts down substantial costs and barriers, particularly associated with moving goods through ports of entry (Makepe, Montsi \& Njoku, 2012).

Despite the long list of known benefits of ICT to the economy, an in-depth study by McKinsey and Company (2014) reflects a rather surprising reality where they found that over $60 \%$ of the global population remained unconnected to the Internet. Such an evidence proves that not everyone has the privilege to gain access to ICT and enjoy all these benefits that come with it. In the case of developing countries for instance, acquisition of ICT itself may pose a challenge mainly because some simply cannot afford to provide the necessary ICT infrastructure and services. For this reason, ICT is available only on a very limited scale, which in turn restrains these underprivileged countries' ability to partake in the existing ICT-induced global knowledge economy. Such circumstance gives birth to a new dimension to existing inequalities and disparities called the digital divide, which pertains to unequal access and usage of ICT across the globe. Countries at low income brackets tend to be positioned at the undesirable end of 
the digital divide, thus putting them at risk of further marginalization by the relatively wealthier countries (Hargittai, 2003).

ICT has proven to be an essential catalyst for growth in many countries around the world $(\mathrm{Vu}$, 2011; Pereira; 2014). ICT use not only has been incorporated in sectors such as manufacturing, education and healthcare, but also in various areas of trade. With the use of ICT, growth in trade activities accelerates through the establishment of electronic commerce (e-commerce) sector, and also through the rise in ICT-producing and -using industries. The motivation of using ICT in trade transpires from how it helps to significantly reduce the cost of doing business, thus enabling firms to market their goods and services at competitively cheaper prices. Park and Koo (1995) in their study mentioned that ICT development helps importers and exporters to cut down their cost of finding out information about the market (search cost), while Hanna (2016) pointed out that ICT helps to lower transport cost and congestion. Moreover, it provides traders with the opportunity to reach the global audience and greater ability to acquire instant market information. Additionally, ICT enables traders to market their products globally without any physical barriers to entry as well as conduct business activities and transactions along the trade chain more conveniently. In short, ICT facilitates trade activities and increases trade efficiency.

Figure 1: Fixed telephone subscriptions, mobile cellular subscriptions and Internet users, in each case measured by per 100 people, in low income and upper middle income countries from year 2006 to 2014

Fixed telephone subscriptions (per 100 people)

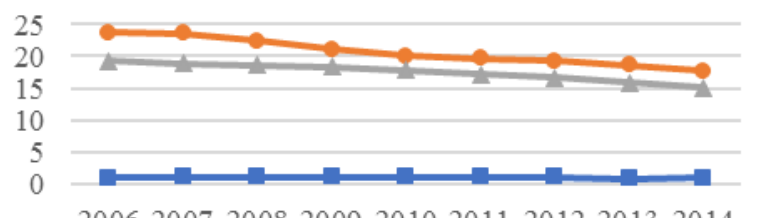

200620072008200920102011201220132014
Mobile cellular subscriptions (per 100 people)

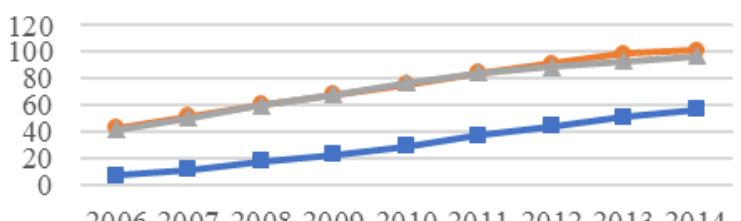

200620072008200920102011201220132014

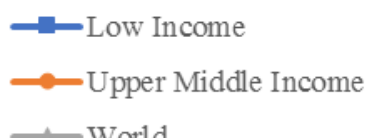

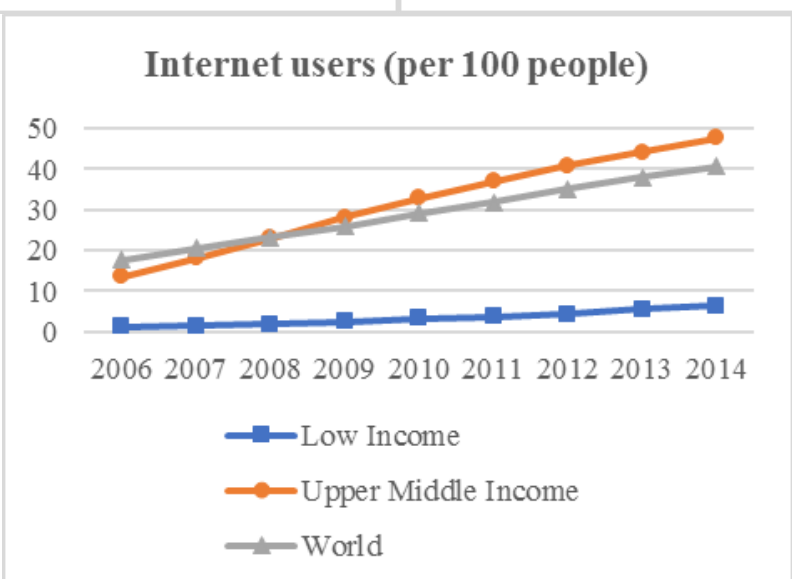

Notes: Horizontal axis represents year and vertical axis represents number of people.

Source: World Bank, 2014

The above diagrams show the distinct disparities in ICT access (fixed telephone and mobile cellular subscriptions) and ICT usage (Internet users) between low income countries, upper middle income countries and the world. Low income countries remain to exhibit the least ICT uptake although they have shown significant progress in mobile cellular subscriptions and a slow growth in Internet users over the years. Fixed telephone subscriptions however, have not shown much improvement and 
continues to be extremely low. According to the Measuring the Information Society Report released by International Telecommunication Union (ITU) in 2015, penetration of fixed telephone in countries like Central African Republic, Malawi, Burkina Faso and Madagascar, fixed telephone penetration remains to be under $1 \%$ in 2014. In the case of upper middle income countries on the other hand, they are experiencing rapid growth in ICT uptake particularly for mobile cellular subscriptions and Internet users, despite the declining number of fixed telephone subscriptions over the course of the last decade.

Given the aforementioned statistics, this study attempts to examine empirically the impacts of ICT on trade in terms of both merchandise and service, an area which is less explored especially involving developing economies. The emphasis on this group of economies is appropriate, because unlike in developed or high income countries where there is high ICT uptake and trade is greatly affected by it (Mattes, Meinen \& Pavel, 2012; Farahani \& Parvardeh, 2012), the impact of ICT on trade in low income and middle income countries remains unclear due to the large variation in access and usage within these developing economies.

The remaining sections of this paper are organized as follows: Section 2.0 reviews the body of literature relating to contribution of ICT to trade, Section 3.0 lays out the data and methodology adopted to carry out the study, while Section 4.0 discusses data analysis and interpretation of statistical findings obtained from the empirical analysis. Section 5.0 summarizes the entire research with relevant conclusions and appropriate recommendations, whereas Section 6.0 addresses the limitation and future research.

\subsection{Literature Review}

There is a vast literature review examining the impacts of ICT on economic growth, but only a few analyzed the impacts of ICT on trade. Although there is a small number of studies investigating the contribution of ICT on trade, evidence from the developing economies remains scarce.

Trade potential for both exporting and importing countries would flourish due to the network characteristic of ICT. An empirical analysis conducted by Farahani \& Parvardeh (2012) in an attempt to explore the impact of ICT on business in Iran, Bahrain, Iraq, Saudi Arabia, Oman, Kuwait, Qatar, and UAE from 2001 to 2009, revealed that business exchanges increase as the countries have better ICT development infrastructures. Using the gravity model as an estimation approach, their results suggest that - after controlling for transportation infrastructure - two trading partners with advanced ICT endowment trade $21 \%$ more than a country pair where one country or both countries have poor ICT development. This evidence is consistent with Mattes et al. (2012), whose results also indicate the significant impact of ICT on European Union (EU) trade, especially when trading partners are advanced users of IT.

Ahmad, Ismail and Law (2011) meanwhile, carried out a similar regional study particularly focusing on Malaysia, also discovered that ICT infrastructure development plays a major facilitating role in reaching higher levels of exports in the region. Also employing an augmented gravity model as the estimation method, their empirical results show that ICT infrastructure variables are statistically significant and have positive impact on Malaysian trade. A study assessing the impacts of infrastructure on trade volume in Asia by Ismail and Mahyideen (2015) have also resulted in positive trade effects by ICT infrastructure for both exporters and importers in the region. Telephone lines and Internet security are the two ICT infrastructure variables that were found to be significant, thus implying that the two should be given more emphasis to reap communication benefits and to facilitate financial transactions between trading partners.

Instead of measuring ICT in terms of its infrastructural aspect only to examine the impact on trade, Liu \& Nath (2013) incorporated 2 additional ICT variables that represent the use of ICT (Internet subscriptions per 100 people and the number of Internet hosts per 100 people) alongside the other 2 variables that are widely used to represent ICT infrastructure (growth of telecom investment and international Internet bandwidth). Using the panel least square (PLS) method and Generalized Method of Moments (GMM) procedure for data estimation and sensitivity checks, empirical findings revealed that Internet subscriptions and Internet hosts have significant positive impacts on both export and import shares in emerging market economies. This goes to show that the trade enhancing effect of ICT does not merely rely on ICT infrastructure or ICT capability, but also on its use. 
Other studies that examine the impact of ICT on specific traded goods such as steel (Shemayev, 2014) and fruits and vegetables (Thiemann, Fleming \& Mueller, 2012) also found that ICT significantly stimulates trade. Chung, Fleming \& Fleming (2013) who investigated whether the use of ICT influences the international trade in fruits and vegetables among members of Asia-Pacific Economic Corporation (APEC) economies, came across contrasting results between exporting and importing activities. Using the gravity model of international trade, empirical findings indicated that changes in ICT levels positively affect the export sector only, while the import sector remains unaffected.

\subsection{Data and Methodology}

Following World Bank's economies classification, low- and middle-income countries were grouped as the developing economies. For the purpose of empirical estimation in this paper, low income countries were selected to represent the ICT have-nots whereas upper middle income were selected to represent the ICT haves. Based on this consideration, a panel dataset consisting of 21 low income countries and 42 upper middle income countries, in each case, on an 8-year period (2007 to 2014) was used. The dependent variables used in this study were two different indicators of economic growth that specifically measure trade, namely merchandise trade (\% of GDP) and service trade (\% of GDP). To analyze the effects of ICT on trade, three measures of ICT development which are fixed telephone subscriptions (per 100 people), mobile cellular subscriptions (per 100 people) and Internet users (per 100 people) were used as independent variables, alongside a set of control variable consisting of GDP per capita, population share and a financial development variable measured by domestic credit to private sector (\% of GDP).

\subsection{Regression Model}

To examine the relationship between ICT and trade, this study adopted the dynamic panel data model of Shiu and Lam (2008) defined as follows:

$G D P_{i t}=\alpha_{i}+\sum_{m=1}^{M} \beta_{m} I C T_{i, t-m}+\sum_{m=1}^{M} \gamma_{m} G D P_{i, t-m}+\mu_{i}+\eta_{t}+v_{i t}$

Based on the above model, GDP and ICT represent the logged GDP growth and ICT respectively; $m$ denotes lag levels of the two said variables; $i$ represents countries; $t$ represents time periods, $\mu_{i}$ refers to unobserved country-specific effects; $\eta_{t}$ refers to time period dummies; and $v_{i t}$ signifies the error term. This study improvises the above model (1.0) by substituting the economic growth indicator with two trade indicators, in addition to a set of control variables, $\mathrm{X}_{i t}$.

$\operatorname{TRDm}_{i t}=\alpha_{i}+\sum_{m=1}^{M} \beta_{m} I C T_{i, t-m}+\sum_{m=1}^{M} \gamma_{m} T R D m_{i, t-m}+\sum_{m=1}^{M} \delta_{m} X_{i, t-m}+\varphi_{t}+\mu_{i t}$
$T R D s_{i t}=\alpha_{i}+\sum_{m=1}^{M} \beta_{m} I C T_{i, t-m}+\sum_{m=1}^{M} \gamma_{m} T R D s_{i, t-m}+\sum_{m=1}^{M} \delta_{m} X_{i, t-m}+\varphi_{t}+\mu_{i t}$

In this model, $\boldsymbol{\alpha}, \boldsymbol{\beta}, \boldsymbol{\gamma}_{,} \boldsymbol{\delta}=$ parameters to be estimated; TRDm = merchandise trade; TRDs = service trade; ICT = ICT developments indicators as measured by fixed telephone subscriptions (TELE), mobile cellular subscriptions (MOB) and Internet users (INTR); $X=$ control variables consisting of GDP per capita (GDP), population share (POP) and financial development variable (FINDEVT); $\boldsymbol{m}=$ level of lags for all variables; $\boldsymbol{i}, \boldsymbol{t}=$ countries in the sample and time periods, respectively; and $\boldsymbol{\mu}_{i t}=$ the composite error term which consists of the unobserved country-specific effect $\left(v_{i t}\right)$ and the observation-specific error $\left(e_{i t}\right)$. 


\subsection{Estimation Method}

Before the primary empirical estimation takes place, diagnostic testing of data was performed. It begins with testing of stationarity of data using several panel unit roots namely Levin-Lin-Chu (LLC) test, Im-Pesaran-Shin (IPS) test and Fisher type tests, followed by testing for poolability of data using the Breusch Pagan LM test. If data cannot be pooled, panel OLS regression is applied. The next step is to proceed with the Durbin-Wu-Hausman test, which is conducted in order to test for endogeneity within the model. If test results show that there is a presence of endogeneity, instrumental variables should be included in the model as well. To decide whether to use instrumental variables (IV) regression or the GMM, heteroskedasticity testing is performed using the Modified Wald test. If the model turns out to suffer from both endogeneity and heteroskedasticity problems, the Arellano-Bond (AB) GMM estimator is applied.

Estimating models (1.1) and (1.2) with panel OLS may produce biased and inconsistent estimates due to the presence of lagged dependent variable as a regressor and the unobserved country-specific effects (fixed effects). Lagged dependent variable gives rise to autocorrelation - correlated with the fixed effect in the error term - and thus, can lead to dynamic panel bias (Nickel, 1981). To mitigate this problem, the fixed effects is eliminated by first-differencing. Therefore, models (1.1) and (1.2) will be estimated in its first-differenced form as follows:

$$
\begin{gathered}
\operatorname{TRDm}_{i t}-\operatorname{TRDm}_{i, t-1}=\alpha_{i}+\sum_{m=1}^{M} \beta_{m}\left(I C T_{i, t-m}-I C T_{i, t-m-1}\right)+\sum_{m=1}^{M} \gamma_{m}\left(\operatorname{TRDm}_{i, t-m}\right. \\
\left.-\operatorname{TRD}_{i, t-m-1}\right)+\sum_{m=1}^{M} \delta_{m}\left(X_{i, t-m}-X_{i, t-m-1}\right)+\left(\mu_{i t}-\mu_{i, t-1}\right) \\
T R D s_{i t}-T R D s_{i, t-1}=\alpha_{i}+\sum_{m=1}^{M} \beta_{m}\left(I C T_{i, t-m}-I C T_{i, t-m-1}\right)+\sum_{m=1}^{M} \gamma_{m}\left(T R D s_{i, t-m}\right. \\
\left.-T^{M} D s_{i, t-m-1}\right)+\sum_{m=1}^{M} \delta_{m}\left(X_{i, t-m}-X_{i, t-m-1}\right)+\left(\mu_{i t}-\mu_{i, t-1}\right)
\end{gathered}
$$

The regression models will be estimated separately using both first-difference GMM and system GMM methods. In the first-difference GMM estimations, the lagged dependent variable will be considered predetermined while the proxies of ICT development will be treated endogenous. Total population on the other hand, will be assumed to be strictly exogenous. Following suggestions made by Andrianaivo and Kpodar (2011) and Farhadi, Ismail, Sarmidi and Kasimin, 2013), predetermined variables are instrumented by their lagged one period or more, endogenous variables are instrumented by their lagged two periods or more, whereas for an exogenous variable, the values are valid instruments regardless of time period. It is important to make a remark here that the first difference of all aforementioned variables will be used as instruments in the level equation for the system GMM estimations.

In order for a GMM approach to produce reliable and consistent estimates, two tests must be passed. First, to test the absence of second order autocorrelation in the residuals of the first-difference equation, Arellano-Bond AR(2) test is applied. Secondly, testing for over-identifying restrictions requires the Sargan test to check the exogeneity of the instruments as a group.

If however any of the regression models turn out to be unfit to GMM estimation, the panel Ordinary Least Squares (OLS) estimator is employed instead. More specifically, the Newey-West method developed by Newey \& West (1987) will be used to correct standard errors in the panel OLS estimator to make them robust and heteroscedasticity and autocorrelation consistent. 


\subsection{Hypothesis Testing}

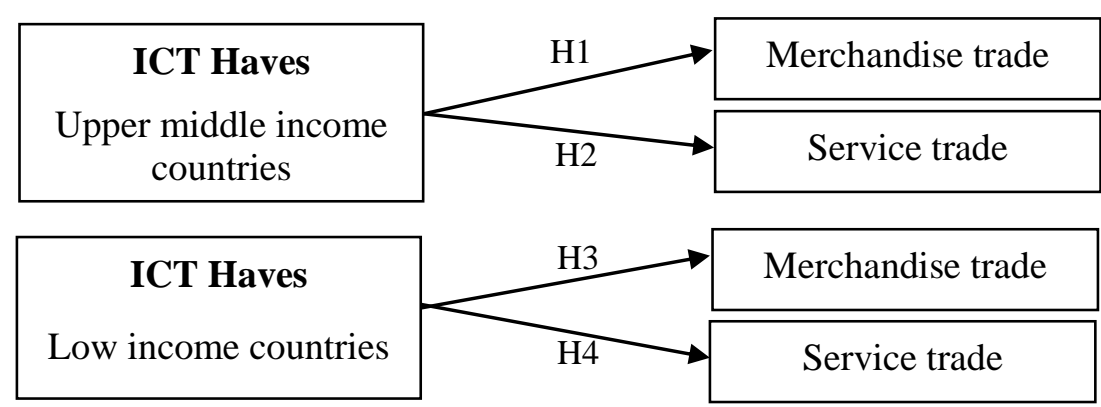

Given the above model, the following hypotheses are developed and tested in order to determine whether ICT has significant and positive impacts on both merchandise trade and service trade among the ICT haves and have nots:

H1: There is a significant and positive relationship between ICT development and merchandise trade of middle income countries.

H2: There is a significant and positive relationship between ICT development and service trade of middle income countries.

H3: There is a significant and positive relationship between ICT development and merchandise trade of low income countries.

H4: There is a significant and positive relationship between ICT development and service trade of low income countries.

\subsection{Findings}

\subsection{Panel Unit Root Tests}

Data analysis begins with testing stationarity of data by performing several panel unit root tests, namely the Levin-Lin-Chu (LLC) test, Im-Pesaran-Shin (IPS) test, Fisher-Augmented Dicky Fuller (FisherADF) and Fisher-Phillips Perron (Fisher-PP) tests on data sets for both low income and upper middle countries. Using the general rule of thumb, lag length selection for all unit root tests begins with a maximum length that equals to the cube root of $T$, which is rounded to $6(\sqrt[8]{168})$ in the case of low income countries and $7(\sqrt[\mathbb{8}]{336})$ in case of upper middle countries. The maximum lags are then pared down until reaching an optimal lag, which is 2 in the case of both low income and upper middle income countries, as per the Akaike Information Criterion (Al Mamun \& Nath, 2005).

In the case of low income countries, only variables INTR and POP were initially found to be nonstationary. For upper middle income countries on the other hand, variables INTR and POP also were nonstationary at first, together with another two variables, TELE and MOB. Such a condition therefore, warrants the transformation of these non-stationary variables into their respective first-differenced forms. This selective transformation of variables is required for models that do not fit GMM estimators, which consequently necessitate the use of panel OLS. For models that fit GMM estimations on the other hand, all variables used will be estimated in their first-differenced forms.

As seen in Table 1 and 2, all first-differenced variables are significant at 5\% confidence level, thus it can be concluded that the data are stationary for both low income and middle income countries.

Table 1: Panel unit root tests for low income countries

\begin{tabular}{|l|c|c|c|c|}
\hline Variable & LLC & IPS & Fisher-ADF & Fisher-PP \\
\hline TRDm & $-16.3114^{* * *}$ & $-9.2708^{* * *}$ & $260.4865^{* * *}$ & $78.5827^{* * *}$ \\
(Merchandise trade) & $(0.0001)$ & $(0.0001)$ & $(0.0001)$ & $(0.0005)$ \\
\hline TRDs & $-23.8414^{* * *}$ & $-7.5156^{* * *}$ & $239.4885^{* * *}$ & $96.2847^{* * *}$ \\
(Service trade) & $(0.0001)$ & $(0.0001)$ & $(0.0001)$ & $(0.0001)$ \\
\hline TELE & $-1.6 \mathrm{e}^{* 002^{* * *}}$ & $-1.9 \mathrm{e}^{+022^{* *}}$ & $415.8150^{* * *}$ & $112.7705^{* * *}$ \\
(Fixed telephone subscriptions) & $(0.0001)$ & $(0.0001)$ & $(0.0001)$ & $(0.0001)$ \\
\hline MOB & $-15.5250^{* * *}$ & $-2.0369^{* *}$ & $142.6331^{* * *}$ & $131.1711^{* * *}$ \\
(Mobile cellular subscriptions) & $(0.0001)$ & $(0.0208)$ & $(0.0001)$ & $(0.0001)$ \\
\hline
\end{tabular}

www.jbrmr.com A Journal of the Academy of Business and Retail Management (ABRM) 


\begin{tabular}{|l|c|c|c|c|}
\hline INTR & $-5.8 \mathrm{e}+02^{* * *}$ & $-96.8455^{* * *}$ & $287.8786^{* * *}$ & $93.3162^{* * *}$ \\
(Internet users) & $(0.0001)$ & $(0.0001)$ & $(0.0001)$ & $(0.0001)$ \\
\hline GDP & $-27.9143^{* * *}$ & $-13.4111^{* * *}$ & $183.1491^{* * *}$ & 51.7346 \\
(GDP per capita) & $(0.0001)$ & $(0.0001)$ & $(0.0001)$ & $(0.1443)$ \\
\hline POP & $-6.7577^{* * *}$ & -0.6371 & $123.8701^{* * *}$ & $102.6882^{* * *}$ \\
(Population share) & $(0.0001)$ & $(0.2620)$ & $(0.0001)$ & $(0.0001)$ \\
\hline FINDEVT & $-32.2221^{* * *}$ & $-6.3880^{* * *}$ & $174.9747^{* * *}$ & $196.4372^{* * *}$ \\
(Financial development) & $(0.0001)$ & $(0.0001)$ & $(0.0001)$ & $(0.0001)$ \\
\hline
\end{tabular}

Notes: Values in parentheses are $\mathrm{p}$-values, where ${ }^{*} \mathrm{p}<.10$; ${ }^{* *} \mathrm{p}<.05$; and ${ }^{* * *} \mathrm{p}<.01$.

Table 2: Panel unit root tests for upper middle income countries

\begin{tabular}{|l|c|c|c|c|}
\hline Variable & LLC & IPS & Fisher-ADF & Fisher-PP \\
\hline TRDm & $-33.2205^{* * *}$ & $-60.2638^{* * *}$ & $508.1928^{* * *}$ & $141.2274^{* * *}$ \\
(Merhcandise trade) & $(0.0001)$ & $(0.0001)$ & $(0.0001)$ & $(0.0001)$ \\
\hline TRDs & $-8.0853^{* * *}$ & $-0.7365^{* * *}$ & $180.5700^{* * *}$ & $272.7206^{* * *}$ \\
(Service trade) & $(0.0001)$ & $(0.0001)$ & $(0.0001)$ & $(0.0001)$ \\
\hline TELE & $-19.3576^{* * *}$ & $-21.9783^{* * *}$ & $545.9242^{* * *}$ & $368.7297^{* * *}$ \\
(Fixed telephone subscriptions) & $(0.0001)$ & $(0.0001)$ & $(0.0001)$ & $(0.0001)$ \\
\hline MOB & $-24.3633^{* * *}$ & $-2.1884^{* * *}$ & $200.2796^{* * *}$ & $259.5277^{* * *}$ \\
(Mobile cellular subscriptions) & $(0.0001)$ & $(0.0001)$ & $(0.0001)$ & $(0.0001)$ \\
\hline INTR & $-6.9 \mathrm{e}+0.2^{* * *}$ & $-3.2 \mathrm{e}+0.2^{* * *}$ & $354.8867^{* * *}$ & $265.2421^{* * *}$ \\
(Internet users) & $(0.0001)$ & $(0.0001)$ & $(0.0001)$ & $(0.0001)$ \\
\hline GDP & $-17.3847^{* * *}$ & $-9.3019^{* * *}$ & $696.1511^{* * *}$ & $277.7699^{* * *}$ \\
(GDP per capita) & $(0.0001)$ & $(0.0001)$ & $(0.0001)$ & $(0.0001)$ \\
\hline POP & $-4.7093^{* * *}$ & $-8.6 \mathrm{e}+0.2^{* * *}$ & $742.0258^{* * *}$ & $657.2665^{* * *}$ \\
(Population share) & $(0.0001)$ & $(0.0001)$ & $(0.0001)$ & $(0.0001)$ \\
\hline FINDEVT & $-17.1313^{* * *}$ & $-3.1232^{* * *}$ & $181.6266^{* * *}$ & $300.3782^{* * *}$ \\
(Financial development) & $(0.0001)$ & $(0.0009)$ & $(0.0001)$ & $(0.0001)$ \\
\hline
\end{tabular}

Notes: Values in parentheses are $\mathrm{p}$-values, where ${ }^{*} \mathrm{p}<.10 ;{ }^{* *} \mathrm{p}<.05$; and ${ }^{* * *} \mathrm{p}<.01$.

\subsection{Empirical Results}

The estimation results for all regression models using panel OLS, difference and system GMM estimators on the sample of 21 low income countries and 42 upper middle income countries over the period 2007 to 2014 are presented in Table 3 and 4, respectively.

Table 3: Panel OLS and GMM estimation results for low income countries

\begin{tabular}{|c|c|c|c|c|}
\hline \multicolumn{2}{|c|}{ Dependent: Merchandise trade (TRDm) } & \multicolumn{3}{|c|}{ Dependent: Service trade (TRDs) } \\
\hline Variable & Panel OLS & Variable & FD-GMM & SYS-GMM \\
\hline L1_TRDm & $\begin{array}{c}0.9643^{* * *} \\
(0.0001)\end{array}$ & L1_TRDs & $\begin{array}{c}0.0864 \\
(0.2540)\end{array}$ & $\begin{array}{c}0.3124^{* * *} \\
(0.0001)\end{array}$ \\
\hline TELE & $\begin{array}{c}0.7538 \\
(0.3460) \\
\end{array}$ & TELE & $\begin{array}{c}-15.8496 \\
(0.1730)\end{array}$ & $8.5894(0.5070)$ \\
\hline $\mathrm{MOB}$ & $\begin{array}{c}0.0727 \\
(0.5870)\end{array}$ & MOB & $\begin{array}{l}0.3626^{*} \\
(0.0710)\end{array}$ & $\begin{array}{c}0.0761 \\
(0.8660)\end{array}$ \\
\hline INTR & $\begin{array}{l}-1.6583 \\
(0.1940) \\
\end{array}$ & INTR & $\begin{array}{c}3.3355 \\
(0.6400)\end{array}$ & $7.2737(0.1480)$ \\
\hline GDP & $\begin{array}{l}-0.0029 \\
(0.4690)\end{array}$ & GDP & $\begin{array}{c}0.0004 \\
(0.9910)\end{array}$ & $\begin{array}{l}-0.0314 \\
(0.4960)\end{array}$ \\
\hline POP & $\begin{array}{l}5.46 \mathrm{e}-08 \\
(0.9630) \\
\end{array}$ & POP & $\begin{array}{l}0.0001^{*} \\
(0.0630)\end{array}$ & $\begin{array}{c}-0.0001 \\
(0.1610) \\
\end{array}$ \\
\hline FINDEVT & $\begin{array}{c}0.0978 \\
(0.2970)\end{array}$ & FINDEVT & $\begin{array}{c}0.9617 \\
(0.2390)\end{array}$ & $\begin{array}{c}1.1540 \\
(0.4240)\end{array}$ \\
\hline constant & $\begin{array}{c}2.8829 \\
(0.4170)\end{array}$ & constant & $\begin{array}{l}15.2831 \\
(0.3490)\end{array}$ & $-7.8426(0.7890)$ \\
\hline F-test & & F-test & & *1) \\
\hline
\end{tabular}




\begin{tabular}{l|c}
\hline BP LM Test & 1.42 \\
& $(0.2328)$ \\
\hline Hausman Test & $41.28^{* * *}$ \\
& $(0.0001)$ \\
\hline R-squared & 0.8579 \\
\hline M. Wald Test & $715.00^{\star * *}$ \\
& $(0.0001)$ \\
\hline
\end{tabular}

\begin{tabular}{|c|c|c|}
\hline BP LM Test & \multicolumn{2}{|c|}{$\begin{array}{c}4.02^{\star *} \\
(0.0451)\end{array}$} \\
\hline Hausman Test & \multicolumn{2}{|c|}{$\begin{array}{l}33.31^{* * *} \\
(0.0001)\end{array}$} \\
\hline R-squared & \multicolumn{2}{|c|}{0.8198} \\
\hline M. Wald Test & \multicolumn{2}{|c|}{$\begin{array}{c}723.44^{* * *} \\
(0.0001)\end{array}$} \\
\hline DWH Test & \multicolumn{2}{|c|}{$\begin{array}{l}3.0280^{*} \\
(0.0849)\end{array}$} \\
\hline $\mathrm{AR}(1)$ & $\begin{array}{c}0.7831 \\
{[0.4336]}\end{array}$ & $-0.6191[0.5359]$ \\
\hline $\mathrm{AR}(2)$ & $\begin{array}{l}-0.1227 \\
{[0.9023]}\end{array}$ & $-1.4855[0.1374]$ \\
\hline Sargan Test & $\begin{array}{c}1.4161 \\
(1.0000)\end{array}$ & $1.4067(1.0000)$ \\
\hline
\end{tabular}

Notes: Panel OLS regressions use Newey west standard errors, whereas both difference GMM (FD-GMM) and system GMM (SYS-GMM) regressions use two-step estimation. Values in parentheses are p-values, where ${ }^{*} \mathrm{p}<.10 ;{ }^{* *} \mathrm{p}<.05$; and ${ }^{* * *} \mathrm{p}<.01$. T-statistics for first and second order correlation are indicated by $\operatorname{AR}(1)$ and $A R(2)$, with their corresponding $p$-values presented in brackets.

As shown in Table 3, the regression model with merchandise trade as dependent variable in the case of low income countries fails to reject the null hypothesis of BP LM test, thus indicating that the panel data are not poolable. In this case, the panel OLS is sufficient to produce efficient estimates by using Newey West standard errors. Although panel OLS estimation results show that none of the ICT variables is significant, two out of the three ICT variables - fixed telephone and mobile cellular subscriptions appear to be positively correlated with merchandise trade. Internet users, in contrast, have insignificant and negative relationship. In addition, all control variables also emerged insignificant, with GDP entering with a wrong negative sign while population share and financial development variables are positively linked with merchandise trade.

Regression model with service trade as the dependent variable on the other hand, rejects the null hypothesis of BM LM test, thus implying that the data can be pooled. Since the Durbin-Wu-Hausman $(\mathrm{DWH})$ test rejects the null hypothesis of exogeneity and suggests that the model contains endogenous regressors, this indicates that the GMM estimator is a more rigorous econometrical technique as compared to the panel OLS estimator. Using both difference and system GMM estimators, results reveal that the lagged dependent variable is highly significant and positively correlated with the dependent variable only when system GMM estimator is used. Difference GMM method produce estimates that render mobile cellular subscriptions as the only ICT variable that is significant out of the three. As for control variables, population share is found to have positive and significant impact on service trade, unlike GDP and financial development, whose insignificant relationships are rather similar to the case of merchandise trade discussed above.

Alternatively, system GMM method seems to produce estimates that are consistent with estimation results from the merchandise trade. Only lagged dependent variable emerged to have high significance and positive impact on service trade. Although none of the ICT variables appear significant, all ICT variables are positively correlated to the dependent variable, thus indicating that ICT gives positive impact on service trade. The same goes to control variables, where only financial development has positive coefficient.

As can be seen in Table 3, the Arellano-Bond test results for both first order, AR(1) and second order, $\mathrm{AR}(2)$ serial correlation also fail to reject the null hypothesis, thus confirming the absence of second order autocorrelation in the residuals of the first-difference equation. Under the joint null hypothesis that instruments used are valid instruments, Sargan test results also correctly fail to reject the null, which suggests exogeneity of the instruments as a group. 
Table 4: GMM estimation results for upper middle income countries

\begin{tabular}{|c|c|c|c|c|c|}
\hline \multicolumn{3}{|c|}{ Dependent: Merchandise trade (TRDm) } & \multicolumn{3}{|c|}{ Dependent: Service trade (TRDs) } \\
\hline Variable & FD-GMM & $\overline{\text { SYS-GMM }}$ & Variable & FD-GMM & SYS-GMM \\
\hline L1_TRDm & $\begin{array}{c}0.0717 \\
(0.1740)\end{array}$ & $\begin{array}{c}0.7842^{* * *} \\
(0.0001)\end{array}$ & $\overline{\text { L1_TRDs }}$ & $\begin{array}{c}0.0686 \\
(0.3760)\end{array}$ & $\begin{array}{c}0.8305^{* * *} \\
(0.0001)\end{array}$ \\
\hline TELE & $\begin{array}{l}-0.4673 \\
(0.5790)\end{array}$ & $\begin{array}{l}-0.1602 \\
(0.8800)\end{array}$ & TELE & $\begin{array}{c}0.4597^{* * *} \\
(0.0080)\end{array}$ & $\begin{array}{c}0.1257 \\
(0.6210)\end{array}$ \\
\hline MOB & $\begin{array}{l}-0.0512 \\
(0.2290)\end{array}$ & $\begin{array}{l}-0.0732^{*} \\
(0.0900)\end{array}$ & MOB & $\begin{array}{c}-0.0295^{* * *} \\
(0.0030)\end{array}$ & $\begin{array}{c}0.0007 \\
(0.9580)\end{array}$ \\
\hline INTR & $\begin{array}{l}0.2957^{* *} \\
(0.0510)\end{array}$ & $\begin{array}{c}0.6257^{* * *} \\
(0.0050)\end{array}$ & INTR & $\begin{array}{c}0.0193 \\
(0.6080)\end{array}$ & $\begin{array}{l}0.1056^{* *} \\
(0.0260)\end{array}$ \\
\hline GDP & $\begin{array}{l}-0.0006 \\
(0.2350)\end{array}$ & $\begin{array}{l}0.0014^{* *} \\
(0.0190)\end{array}$ & GDP & $\begin{array}{c}-0.0003^{* * *} \\
(0.0060) \\
\end{array}$ & $\begin{array}{c}-0.0009^{* * *} \\
(0.0001)\end{array}$ \\
\hline POP & $\begin{array}{c}-7.66 \mathrm{e}-06 \\
(0.4640)\end{array}$ & $\begin{array}{c}-4.45 \mathrm{e}-06 \\
(0.2310)\end{array}$ & POP & $\begin{array}{l}2.18 \mathrm{e}-06 \\
(0.5160)\end{array}$ & $\begin{array}{c}-1.79 \mathrm{e}-06 \\
(0.2380)\end{array}$ \\
\hline FINDEVT & $\begin{array}{c}0.1463^{* * *} \\
(0.0100)\end{array}$ & $\begin{array}{l}-0.0474 \\
(0.5230)\end{array}$ & FINDEVT & $\begin{array}{l}-0.0316 \\
(0.2320)\end{array}$ & $\begin{array}{l}-0.0135 \\
(0.5300)\end{array}$ \\
\hline constant & $\begin{array}{l}70.8497^{* * *} \\
(0.0001)\end{array}$ & $\begin{array}{l}10.0345 \\
(0.0930) \\
\end{array}$ & constant & $\begin{array}{c}25.3451^{* * *} \\
(0.0001)\end{array}$ & $\begin{array}{l}-0.0497 \\
(0.9700)\end{array}$ \\
\hline F-test & \multicolumn{2}{|c|}{$\begin{array}{c}304.70^{* * *} \\
(0.0001)\end{array}$} & F-test & \multicolumn{2}{|c|}{$\begin{array}{c}1602.10^{* * *} \\
(0.0001)\end{array}$} \\
\hline BP LM Test & \multicolumn{2}{|c|}{$\begin{array}{c}3.90^{\star *} \\
(0.0484)\end{array}$} & BP LM Test & \multicolumn{2}{|c|}{$\begin{array}{l}13.07^{* * *} \\
(0.0003)\end{array}$} \\
\hline Hausman Test & \multicolumn{2}{|c|}{$\begin{array}{l}121.18^{* * *} \\
(0.0001)\end{array}$} & Hausman Test & \multicolumn{2}{|c|}{$\begin{array}{l}87.25^{* * *} \\
(0.0001)\end{array}$} \\
\hline R-squared & \multicolumn{2}{|c|}{0.8880} & R-squared & \multicolumn{2}{|c|}{0.9749} \\
\hline M. Wald Test & \multicolumn{2}{|c|}{$\begin{array}{c}201.93^{* * *} \\
(0.0001)\end{array}$} & M. Wald Test & \multicolumn{2}{|c|}{$\begin{array}{c}241.73^{* * *} \\
(0.0002)\end{array}$} \\
\hline DWH Test & \multicolumn{2}{|c|}{$\begin{array}{l}3.1209^{*} \\
(0.0788)\end{array}$} & DWH Test & \multicolumn{2}{|c|}{$\begin{array}{l}3.3670^{*} \\
(0.0680)\end{array}$} \\
\hline $\mathrm{AR}(1)$ & $\begin{array}{c}0.5466 \\
{[0.5846]}\end{array}$ & $\begin{array}{c}-3.1002^{* * *} \\
{[0.0019]}\end{array}$ & $\mathrm{AR}(1)$ & $\begin{array}{c}-0.5455 \\
{[0.5854]}\end{array}$ & $\begin{array}{c}-4.7793^{* * *} \\
{[0.0001]}\end{array}$ \\
\hline $\mathrm{AR}(2)$ & $\begin{array}{l}-1.0275 \\
{[0.3042]}\end{array}$ & $\begin{array}{l}-1.4588 \\
{[0.1446]}\end{array}$ & $\mathrm{AR}(2)$ & $\begin{array}{l}-0.4210 \\
{[0.6738]}\end{array}$ & $\begin{array}{c}-0.3731 \\
{[0.7091]}\end{array}$ \\
\hline Sargan Test & $\begin{array}{l}24.3076 \\
(0.9983)\end{array}$ & $\begin{array}{l}31.2626 \\
(1.0000)\end{array}$ & Sargan Test & $\begin{array}{l}30.8255 \\
(0.9744)\end{array}$ & $\begin{array}{l}16.5113 \\
(1.0000)\end{array}$ \\
\hline
\end{tabular}

Notes: Both difference GMM (FD-GMM) and system GMM (SYS-GMM) regressions use two-step estimation. Values in parentheses are $p$-values, where ${ }^{*} p<.10$; ${ }^{* *} p<.05$; and ${ }^{* * *} p<.01$. T-statistics for first and second order correlation are indicated by $\operatorname{AR}(1)$ and $A R(2)$, with their corresponding p-values presented in brackets.

In the case of upper middle income countries, all regression models appear to fit GMM estimation methods, as their BP LM and DWH Test results for both merchandise trade and service trade, are all significant at $5 \%$, signifying that data can be pooled and the models suffer from endogeneity problem.

As tabulated in Table 4 above, difference and system GMM estimators for regression model using merchandise trade as dependent variable show contrasting results. Estimates produced by difference GMM estimator found that only Internet users and financial development are significantly and positively linked to merchandise trade. The rest of the variables are insignificant and enter with negative coefficients, except the lagged dependent variable which enters with a positive coefficient. System GMM estimators on the other hand, produced estimates that render mobile cellular subscriptions as another significant ICT variable, alongside Internet subscriptions. Unlike results from difference GMM, GDP and lagged dependent variable in this case appear highly significant and have positive impact on merchandise trade.

With respect to service trade, results from difference GMM estimators reveal that fixed telephone subscriptions and mobile cellular subscriptions are the two ICT variables that significantly influence 
service trade. However, mobile cellular subscriptions is the only ICT variable that has positive relationship with the dependent variable. GDP also appears significant, but enters with a wrong negative sign. The remaining variables, including lagged dependent variable, is not significantly correlated. Alternatively, system GMM method seems to produce a more reliable estimate. Not only does the lagged dependent variable emerged to have high significance and positive impact on service trade, GDP too appears highly significant, although being negatively correlated to the dependent variable. Only one out of the three ICT variables show significance at $5 \%$ and positive relationship with service trade, and that is Internet subscriptions. Nonetheless, fixed telephone subscriptions and mobile cellular subscriptions appear to have positive impacts on service trade, although they are both insignificant. Population share and financial development variables on the other hand, are negatively and insignificantly linked to the dependent variable.

Based on the results of autocorrelation tests of AR (1) and AR (2), as well as the Sargan test for all regression models presented in Table 4, their corresponding p-values fail to reject their respective null hypotheses, thus confirming that there is no second order autocorrelation in the residuals of the firstdifference equation and the orthogonality conditions of the instrument variables are fulfilled.

\subsection{Conclusion and Recommendation}

This study has investigated with various estimation methods the role of ICT variables alongside several control variables, in explaining trade on a sample of 42 upper middle income and 21 low income countries, representing the ICT haves and ICT have-nots respectively, over the 2007 to 2014 period.

The empirical findings conclude that low income countries are still very much dependent on traditional forms of technologies in its trade activities. Although the ICT variables appear to positively influence trade, their corresponding insignificance could be due to the actual number of ICTs in the countries being too small to give impacts on trade. Given the low income levels in the countries, the lack of ICT penetration and access might stem from the fact that the costs of acquiring and providing ICT good and services is relatively higher as compared to wealthier countries. ITU (2015) in their report pointed out that price of fixed-broadband and mobile broadband services remains high and relatively less affordable for the low income and developing countries. Low income countries also encounter problem in gaining access to advanced ICTs, thus leaving them to depend on traditional forms of ICT such as the telephone (UNCTAD, 2010). Though there could be significant role of ICT on the economic growth as a whole for low income countries, this paper however did not find any significant influence of ICT, particularly on trade.

With regard to upper middle income countries, mobile cellular subscriptions and Internet users are the two ICT variables that appear significant in merchandise trade, while in service trade, only Internet users emerge significant. The insignificance of fixed telephone subscriptions in trade for upper middle income countries suggests that there could be a decreasing reliance on lower-level and traditional forms of ICT. Mobile cellular and the Internet, that are far more sophisticated than the fixed telephone, have proven its contribution on trade activities in these economies. As evidenced by the empirical findings, Internet users have positive impact on both merchandise trade and service trade, although the impact is much greater in term of merchandise trade. The significance of Internet in this case, is consistent with findings from Liu and Nath (2013). Mobile cellular subscriptions, however, has an unexpected negative influence on merchandise trade.

As far as the control variables are concerned, none appears significant for low income countries, whereas only GDP has significant influence on trade for upper middle income countries. Population share and financial development on the other hand, do not seem to have significant effect on trade in neither of the developing economies. Positive and highly significant impact of lagged dependent variable for both low income and upper middle income countries on trade, infers that maintaining high levels of trade can lead to higher rate of trade in the subsequent period.

Findings from empirical analysis of this study raise doubt regarding the potential of ICT in making substantial contribution to trade particularly for low income countries. This could be due to several obvious constraints such as high cost of providing access to ICT and inadequate physical infrastructure that facilitates access to more advanced forms of technologies. This paper therefore, suggests to reduce in stages the above mentioned constraints. Policies targeted at stimulating competition 
in the ICT sector as well as incentives for cost reduction and innovation, can help these low income countries not only to gain access to ICT at a much affordable price, but simultaneously improve their productivity and trade growth. As for upper middle income countries, more emphasis should be placed on the newer forms of technologies like mobile cellular and the Internet. The governments should put in place targeted strategies and inducements for traders to further embrace ICT in their business in effort to facilitate trade and unlock more trading opportunities. Ultimately, all of the above initiatives should go hand in hand with providing equitable access to vital utilities such as electricity, as well as basic needs such as education, to unleash the full potential of ICT nationwide. Existing infrastructure should also be improved from time to time to deliver better ICT services to the people.

\subsection{Limitations and Future Research}

As this study examined the impact of ICT on both merchandise and service trades of low income and middle income countries, missing or unavailable data is one of the limitations faced by the researcher particularly for countries belonging in the low income bracket. For this reason, the initial number of countries sampled had to be reduced where only those with complete data were selected and included in the final sample. In addition, this study only managed to obtain full dataset for 3 types of ICT (fixed telephone, mobile cellular and the Internet) that are used as proxies representing ICT access and usage, when in fact there are other types of ICTs like the personal computers and mobile broadband that can be used as well. Thus, these other types of ICT had to be omitted from the regression models due to the limited statistical records that quantify their access and usage.

This study recommends that future research include longer time period and larger sample. Since this study focused on low income and middle income countries, future research may also cover high income countries as well. Additionally, trade was the only economic indicator tested for its relationship with ICT in this study, hence, future research may incorporate other economic indicators such as GDP growth and savings.

\section{References}

Ahmad, N. A., Ismail, N. W. Ismail \& Law, S. H. (2011). The role of ICT infrastructure on Malaysian trade. Journal of Economics and Management, 5(1), 140-148.

Al Mamun, K. A. \& Nath, H. K. (2005). Export-led growth in Bangladesh: a time series analysis. Applied Economics Letters, 12, 361-4.

Andrianaivo, M. \& Kpodar, K. (2011). ICT, financial inclusion, and growth evidence from African countries. International Monetary Fund Working Paper 11/73.

Chung, K. C., Fleming, P. \& Fleming, E. (2013). The impact of information and communication technology on international trade in fruit and vegetables in APEC. Asian-Pacific Economic Literature, 27(2), 117130.

Farahani, T. \& Parvardeh, R. (2012). The impact of ict on trade in Persian Gulf countries. Iranian Economic Review, 16(32).

Farhadi, M., Ismail, R., Sarmidi, T. \& Kasimin, H. (2013). The role of information and communication technology development in economic growth: A dynamic panel data approach. Advances in information Sciences and Service Sciences (AISS), 5(12).

Hanna, N. K. (2016). Mastering digital transformation: Towards a smarter society, economy, city and nation (1st ed.). Emerald Group Publishing Limited.

Hargittai, E. (2003). The digital divide and what to do about it. Pp. 822-839 in The New Economy Handbook, edited by Derek C. Jones. San Diego, Calif: Academic Press.

International Telecommunication Union. (2015). Measuring the Information Society Report. Place des Nations CH-1211 Geneva, Switzerland.

Ismail, N. W. \& Mahyideen, J. M. (2015). The impact of infrastructure on trade and economic growth in selected economies in Asia. ADBI Working Paper 553. Tokyo: Asian Development Bank Institute.

Liu, L. \& Nath, H. K. (2013). Information and communications technology and trade in emerging market economies. Emerging Markets Finance \& Trade, 49(6), 67-87.

Makepe, P. M., Montsi, K. \& Njoku, C. (2012). Information and communication technologies (ICTs) enabled trade facilitation in Botswana. Pula: Botswana Journal of African Studies, 26(1). 
Mattes, A., Meinen, P. \& Pavel, F. (2012). Goods follow bytes: The impact of ICT on EU trade. DIW Working Paper 1182.

McKinsey \& Company. (2014). Offline and falling behind: Barriers to Internet adoption.

Newey, W. K. \& West, K. D. (1987). A simple, positive semi-definite, heteroskedasticity and autocorrelation consistent covariance matrix. Econometrica, 55: 703-708.

Park, M. H. \& Koo, W. W. (1995). Recent Development in Infrastructure and Its Impact on Agricultural and Non-agricultural Trade. Paper presented at the American Agricultural Economics Association Annual Meeting, Providence, Rhode Island.

Pereira, F. (2014). The role of information communication technology policies in economic development: A comparison of select Asian countries. Retrieved from

https://ideas.repec.org/p/zbw/itsb14/106871.html

Shemayev, V. (2014). An alloy of steel and information and communication technology (ICT): Does it facilitate trade?. Theses, Dissertations, Professional Papers, Paper 4281.

Shiu, A. \& Lam, P. L. (2008). Causal relationship between telecommunications and economic growth: a study of 105 countries. Paper presented at the 17th Biennial Conference of the International Telecommunications Society. Montreal.

Thiemann, F., Fleming, E. \& Mueller, R. A. E. (2012). Impact of information and communication technology (ICT) on international trade in fruit and vegetables: A gravity model approach. The International Association of Agricultural Economists (IAAE).

$\mathrm{Vu}, \mathrm{K} . \mathrm{M}$. (2011). ICT as a source of economic growth in the information age: empirical evidence from the 1996-2005 period. Telecommunications Policy, 35(4), 357-372.

World Bank. (2014). World Development Indicators. World Bank, Washington, D.C. 